\title{
7
}

\section{Origins of Family Policy: Prerequisites or Diffusion}

\author{
Tobias Böger, Keonhi Son, and Simone Tonelli
}

\section{Introduction $^{1}$}

Compared to other areas of social policy, the historical origins of family policy, i.e., the public provision of cash, time, and services to assist

${ }^{1}$ This chapter is a product of the research conducted in the Collaborative Research Center "Global Dynamics of Social Policy" at the University of Bremen. The center is funded by the Deutsche Forschungsgemeinschaft (DFG, German Research Foundation)-project number 374666841-SFB 1342.

T. Böger $(\bowtie) \cdot$ K. Son $\cdot$ S. Tonelli

University of Bremen, Bremen, Germany

e-mail: boeger@uni-bremen.de

K. Son

e-mail: son@uni-bremen.de

S. Tonelli

e-mail: si_to@uni-bremen.de 
child-rearing and reconcile care and work, have received only scant attention. Gauthier's book (1996) remains the definitive comparative in-depth study of the diverse origins and trajectories of family policy in the countries that now belong to the group of rich, democratic welfare states. Comparative studies with a Latin-American (Blofield and Martinez Franzoni 2015; Blofield and Touchton 2020), East-Asian (Fleckenstein and Lee 2017; Saraceno 2016), and even a global focus (Filgueira and Rossel 2020) have started to appear, but for the most part, ignore the historical roots of the policies they study. We provide the first global analysis of the origins of family policy, systematically testing established theories and propositions. This facilitates an assessment of the influence of international linkages on the development of family policy, which is widely acknowledged but proves difficult to pin down (White 2020).

While contemporary family policies are often analyzed as a more or less coherent "whole", which can be characterized along dimensions such as "defamilization" or typologized according to how these policies structure gender relations within the family, state interest in and support for families historically first appeared as "piecemeal interventions" rather than "comprehensive packages" (Gauthier 1996). It took more than half a century before family policies (plural) coalesced into a distinct and explicit family policy (singular), and even then, state intervention often remained far from coherent. Since we are interested in the historical origins of family policy, we look at the adoption of paid maternity leave, child benefits, and workplace childcare regulations in isolation, i.e., analyzing the first adoption of each of these family policies. This also poses a relatively "easy" test for the effect of international linkages, which may wither away or work differently following these first adoptions.

To give an overview of the historical origins, to assess the types of domestic drivers put forward, and to gauge possible channels of diffusion, we first review the literature dealing with the three types of family policy. Then, we present data and models and appraise the generalizability of earlier findings across time and space. A brief discussion of methodological and substantive limitations concludes. 


\section{Family Policies: Historical Origins and Drivers ${ }^{2}$}

\section{(a) Paid Maternity Leave}

Paid maternity leave policy was the earliest social protection policy explicitly aimed at women workers. While other protective legislation, such as unpaid maternity leave and the prohibition of night work, often had adverse effects on women's economic empowerment by limiting the job opportunities of women workers, paid maternity leave policy minimizes the difficulties of working mothers that go along with giving birth without jeopardizing their economic independence (Htun et al. 2019). Because paid maternity leave policies provide income compensation and often prohibit employers from dismissing women workers during and after confinement, they secure their independence vis-à-vis their employers and spouses. Whereas the different factions within the women's movement disagreed on whether women-specific labor laws were needed to achieve gender equality in the labor market, they agreed on the necessity of paid maternity leave (Berkovitch 1999; Boris 2019).

Despite this fundamental role in providing social protection for women workers, little is known about the historical development of paid maternity leave policies. Historical accounts of social protection programs focus on the risks of old age, unemployment, and sickness (Esping-Andersen 1990; Flora and Heidenheimer 1981), often treating paid maternity leave only as a corollary to the general development of social insurance principles. This research gap reflects the fact that the unit of analysis in early comparative welfare state research has always been the average production worker in the manufacturing industry with a dependent spouse and two children, assuming, if not reflecting, the gendered division of labor (Orloff 1993; Sainsbury 2001). While feminist studies criticized this male breadwinner-centric conceptualization and measurement of social rights, their own studies focused on the more recently introduced childcare and parental leave policies. While pivotal

\footnotetext{
${ }^{2}$ The history and analysis of paid maternity leave was authored by Keonhi Son, of child benefits by Simone Tonelli and of workplace childcare by Tobias Böger.
} 
to the question of how contemporary welfare states shape gender relations (Leitner 2003; Saraceno 2011), these studies shed little light on the forces that have "gendered" the welfare state since its beginnings.

The few studies that focus on the historical development of paid maternity leave emphasize the significant role of domestic actors and institutional developments. Gauthier argues that the fear of "family decline" following industrialization and urbanization in early twentiethcentury Europe triggered government responses, including paid maternity leave (Gauthier 1996). Case studies of European countries and the U.S. have also emphasized the role of female agency (Hobson and Lindholm 1997; Koven and Michel 1990; Sainsbury 2001). A recent publication from Son and Böger expands the research scope to the global scale and finds that women's political empowerment and the general expansion of social protection policies have contributed to the extension of access to maternity benefits from the 1880s to 2018 (Son and Böger 2021).

Among the scant studies of national maternity leave introduction, processes of observation of legislative activity in other countries rarely figure in and neither do references to norms set by global bodies. This is surprising because maternity protection was an agenda that arose with the founding of the International Labour Organization (ILO) and has continued to be a salient issue ever since. In the early twentieth century, women's movements struggled to introduce and extend the right to maternity benefits by lobbying the ILO to adopt the Maternity Protection Convention, which functioned as an important organizational platform spreading maternity protection policies at the nation-state level (Berkovitch 1999). The ILO adopted the first Maternity Protection Convention (C003) when it was founded in 1919 during its first conference and has since updated the standards for maternity protection every three decades in two consecutive Maternity Protection Conventions (C103, C183), in 1952 and 2000. The ILO had been the only standardsetter until the European Union implemented its own standards in 1992 (Pregnant Worker Directive 92/85/EEC) (Linos 2013, 130-131). Son and Böger (2021) find that nation-states tend to extend the coverage and lower the eligibility criteria of maternity benefits shortly after they 
join the ILO. Their findings also signal the significant effect of longstanding membership, implying that the ILO consistently contributes to the extension of paid maternity leave policies by utilizing technical expertise and continuous dialogue with national governments.

Another strand of studies emphasizes the impact of colonial domination and legacies on welfare systems in the Global South. Schmitt $(2015,2020)$ finds that nation-states that share the same colonial experience are likely to introduce social protection programs at a similar time, as colonizers often institutionalized social policies in response to a rise of labor strikes in the 1940s. Importantly, France introduced a unified labor code that mirrored the French labor code in all French colonies to stabilize the labor issue, namely the French Code du Travail (1952) which provided family allowances and maternity insurance for wage earners (Cooper 1996). Despite the limited coverage of the French Code $d u$ Travail, its adoption brought about the introduction of paid maternity leave in 14 of 39 Sub-Saharan African countries with a generous amount of benefit (half of the previous wage) and a substantial duration of benefit (14 weeks) in the early phase of economic development (1952) in comparison to other middle- and low-income countries.

Overall, the literature points toward the influence of the ILO (ILO hypothesis) and the reaction of colonial administrations to labor unrest (colonial hypothesis) as the main drivers of paid maternity leave introduction.

\section{(b) Child Benefits}

Early forms of child benefits, then mostly referred to as "family allowances," were introduced during World War I as a way to compensate for the separation of men in the armed forces and their families, largely because it was found difficult to recruit them otherwise (Land 1985). These benefits were quickly withdrawn after the end of the conflict, but the economic hardship, mounting unemployment, and political turmoil of the interwar period brought home the importance of having an income stabilizer for large families (Hoffner 1935). The acknowledgment that having children was associated with a higher risk of poverty 
helped establish the principle that workers' salaries should also be a function of the size of their families. Such a principle pushed some advocates of eugenics to argue against the introduction of family allowances, as it would have only increased "the rate of multiplication" of individuals at the bottom of the social scale (Darwin 1925). However, fear of depopulation prevailed over arguments of eugenics, and family allowances were introduced as a form of population policy to counter falling birth rates (Gille 1954; Watson 1954a, b).

All in all, it is hard to find a single driver for the adoption of family allowances. An overview of early writings on the topic highlights three major arguments that were put forward in support of their adoption. First, family allowances were considered a way to compensate a family for the consequences of war, be it the absence of the breadwinner or the economic hardship that followed the two world wars (compensation hypothesis) (Breul 1953; Doublet 1948; Kitchen 1981; Land 1985). Second, family allowances were intended as a living wage, i.e., adjusted for family size (redistribution hypothesis) (Campbell 1927; Cousins 1999; Hoffner 1935, 1940; Land 1985; Rathbone 1940), and finally, family allowances were intended as a means to counter falling birth rates (population hypothesis) (Biagi 1937; Campbell 1927; Cousins 1999; Gille 1954; Hoffner 1935, 1940; Land 1985; Watson 1954b).

Although these three hypotheses advance our understanding of the mechanisms that might drive the adoption of family allowances, there have been few systematic attempts to test them. Partial support for the compensation hypothesis can be found in recent contributions that include some form of family benefits in the analysis. The authors find evidence that the two world wars were a catalyst in the development of European welfare legislation (Obinger and Schmitt 2020). Furthermore, Schmitt (2020) argued that mass conscription during WW2 in French African colonies advanced the cause of extending social rights to groups previously excluded. In support of Schmitt's argument, previous research has shown a positive statistical association between the timing of the introduction of family benefits and a colonial link to France (Kangas 2012; Schmitt et al. 2015). Misra $(1998,2003)$ provides support of the redistribution hypothesis, showing that the working class and women's 
movement were important factors leading to family allowance adoption in 18 industrialized countries. An empirical test of the population hypothesis in the literature is missing, however, an association between fertility levels and the development of certain family benefits has been suggested (Ferrarini 2006).

Finally, recent scholarship in social policy diffusion has started to investigate the effect of state interdependencies on the introduction of early programs. Studying countries' colonial relationships, Schmitt et al. (2015) present evidence that French and British colonial links impacted the timing of adoption of family benefits. French colonial ties accelerated the timing of the introduction of family benefits, while British colonial ties slowed it down, even in the postcolonial era.

\section{(c) Workplace Childcare Regulation}

The public provision of care for children, especially those under three years old, was only weakly institutionalized in many countries until recently (O'Connor 1990). However, governments in the early twentieth century, as well as today, also utilized labor regulation to promote the availability of childcare for young children without having to step in as a provider themselves. Factory (or workplace) crèches or nurseries were an early institution catering to working mothers. While these have become less widespread in European countries after the second world war, factory crèches and nurseries remain a viable avenue for work-family reconciliation across the globe even today (Hein and Cassirer 2010).

There are multiple historical antecedents of factory crèche legislation. In Europe, there was the charitable provision of childcare, promoted by F. Marbeau in France, as well as early philanthropic endeavors by businessmen, such as R. Owen's experiments in workplace education in the factories of New Lanark, Scotland (Caroli 2019). These were driven, among other motives, by a shared concern for the health of newborn children, notably, the fear of rising infant mortality. At the time, they were the first institutions that did not provide care to the illegitimate children of the poorest of the poor, but responded to the needs of working mothers. State intervention was pioneered in France: While the 
legislation passed in 1867 and 1897 only regulated crèches run as charitable institutions, government interest began to shift as young women entered the labor market. When female labor was needed in the production of ammunition during World War I, the French Act of the 5th of August 1917, prescribed the provision of nurseries to any establishment employing more than 100 women over 15 years old. It marked the first introduction of regulatory measures, obliging private employers to provide relatively extensive childcare arrangements in Europe (Burger 2012; Reynolds 1990). Even though—or perhaps because—it was only perceived as a "second-best" option by the left-wing socialists as well as the right-wing pronatalists, after the War, the factory crèche had become a highly visible and highly legitimate institution (Reynolds 1990).

This convergence of various political forces on the issue of infant mortality and female employment is also apparent in a wide array of countries, which adopted similar policies in the early twentieth century. Among these were the fascist regime in Italy (1925/1926) and the Soviet Union (1932) (Caroli 2019), but also the late-late-developing countries of the southern cone of Latin America: Chile (1917) and Argentina (1924) (Aguilar 2018; Casas and Herrera 2012).

However, the parallel adoption of workplace childcare regulations may also have been triggered by processes of diffusion. Caroli (2019) notes that the observation of French practices and models of childhood development helped foster the introduction of crèches in Italy and Russia, but also contends that national peculiarities shaped each country's unique institutionalization of the crèche. While the ILO was involved in devising standards for the employment of pregnant women and mothers from its foundation onwards, it was not until after the Second World War that it took on the issue of care in one of its recommendations (Maternity Protection Recommendation 95 in 1952; Workers with Family Responsibilities Convention 156 in 1981). However, the ILO never committed itself to the private provision of facilities, emphasizing the need for public financing, regulation, and clearly expressing preference for provisions outside of the workplace.

Since no systematic comparative study of workplace childcare regulation has been undertaken so far, and the available historical literature 
refrains from generalizing, our analysis of legislation remains mostly explorative.

\section{Data and Methods}

The models in this chapter closely follow the framework laid out in the introduction, which is based on the work by Valente (1995). The dates of adoption were generated using newly collected data of legislative activity in three main areas of family policy: paid leave, child benefits, and public care (Son et al. 2020; Tonelli et al. 2021). Figures 7.1, 7.2, and 7.3 show the spatial distribution of adoptions over time. To accommodate the field of family policy, two key independent variables are added. The total fertility rate (Gapminder 2020) reflects demographic pressures, which have often been hypothesized to trigger state intervention in families. Given that we are concerned only with the first adoptions of policies, higher fertility rates should decrease the hazard of adopting a family policy, especially family allowances. The membership in the ILO captures an additional type of international linkage, which may facilitate (vertical) diffusion. Since the ILO's advocacy for family allowances and workplace

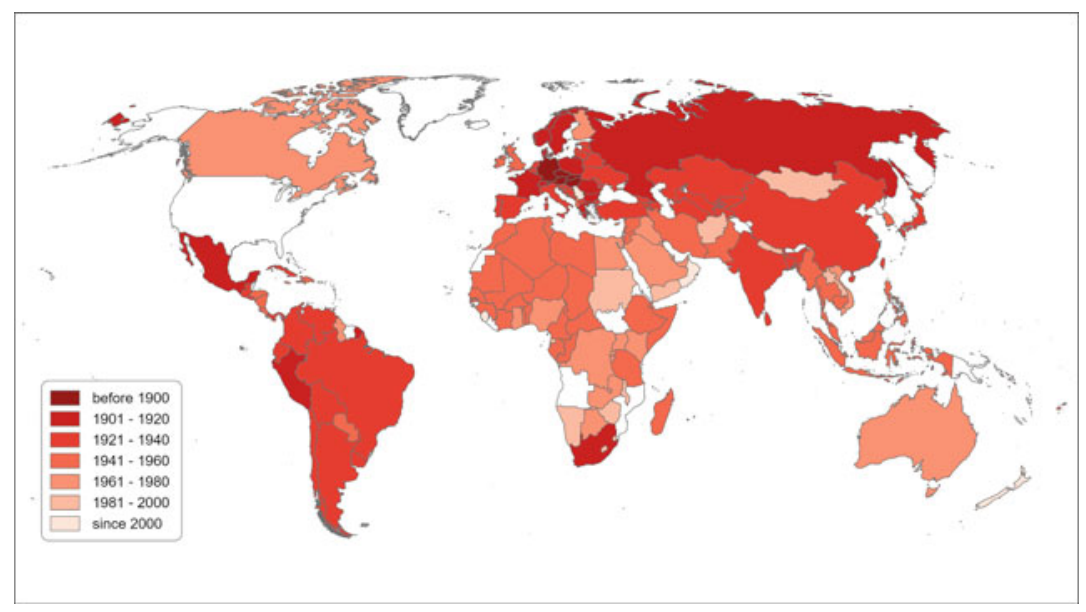

Fig. 7.1 The introduction of paid maternity leave 


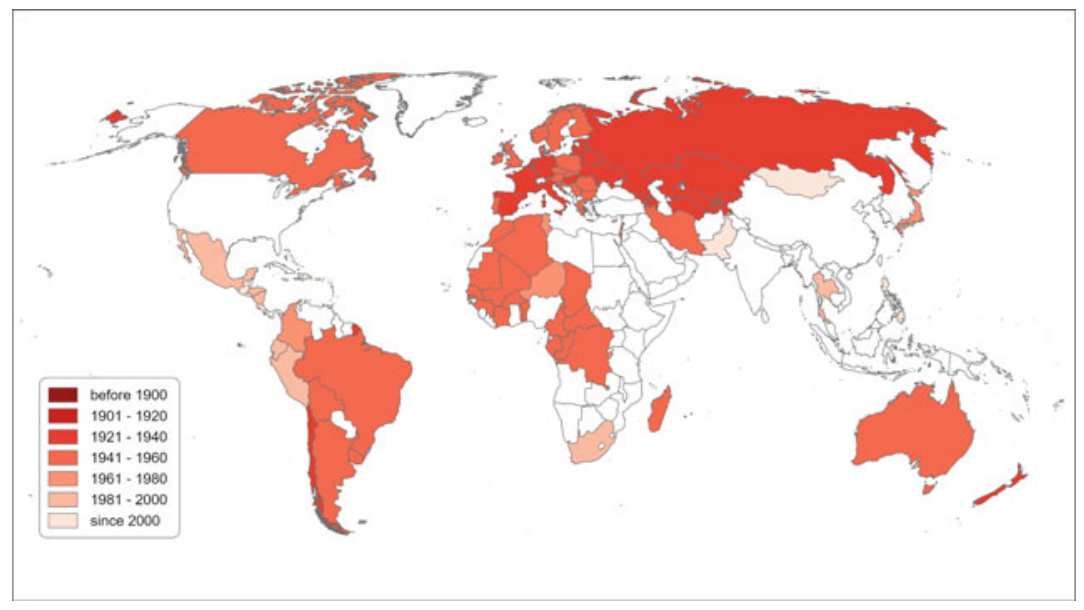

Fig. 7.2 The introduction of child benefits

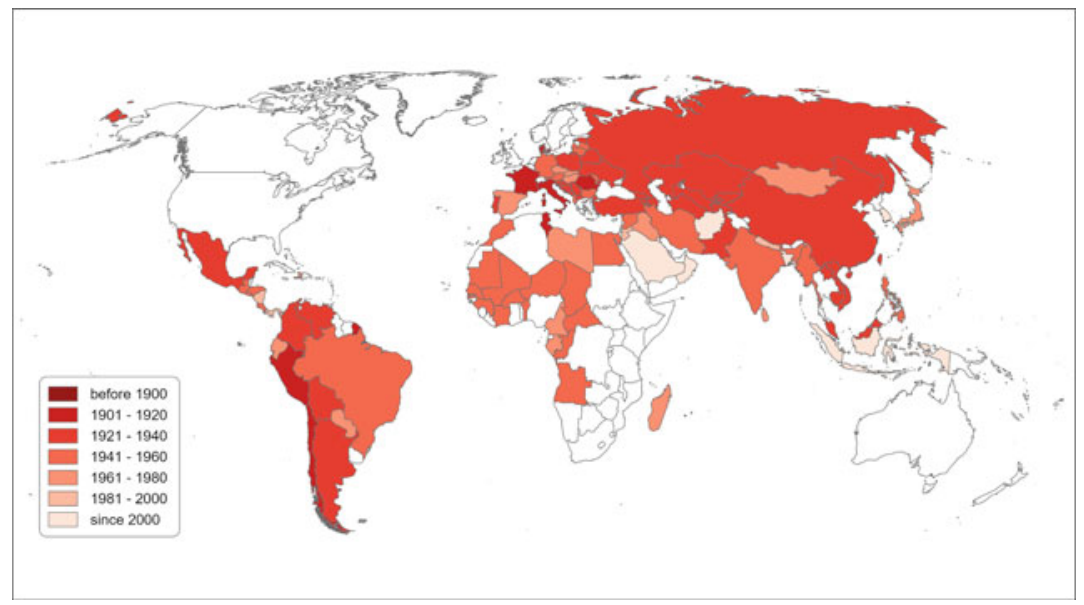

Fig. 7.3 The introduction of workplace childcare regulation

childcare regulations has been limited in scope and its commitment to paid maternity leave has been renewed three times over the past hundred years, we expect ILO membership to exert the strongest influence on the adoption of paid maternity leave. 
Regarding the other control variables, we do not hypothesize specific effects for two reasons. First, family policy does not possess any elective affinity to democracy. Pronatalist family policy developed in fascist regimes in the context of "authoritarian, largely anti-modern but also nationalist familism" and as a project of the democratic left as a part of social reform (Therborn 2004). Second, we expect policy diffusion prompted less developed countries to adopt family policies at an early stage of economic development, therefore nullifying the effect of the degree of economic development (Collier and Messick 1975).

\section{(a) Maternity Leave}

Table 7.1 shows the results of five discrete-time logistic hazard models, first displaying each type of network exposure separately then combined, thus capturing different potential avenues of diffusion. While we find little surprise in our results, three observations warrant elaboration. First, the stepwise-time-function is highly significant across models. While we refrain from its substantive interpretation in terms of hazard ratios, this indicates that unobserved heterogeneity matters. Substantively, this is taken to imply that global trends, which affect all countries, influence the likelihood of the adoption of maternity leave. While these may in part consist of concurrent changes in domestic conditions, it may also reflect truly global developments, such as the intensification of global trade or the promulgation of global norms by the ILO and other standard-setting bodies, i.e., the activities of global "rationalized others" as hypothesized by world society theory (Meyer et al. 1997). Second, and in line with expectations, we find that membership in the ILO increases the hazard of introducing paid maternity leave by $65-82 \%$. The strength of this effect is especially noteworthy when compared to the weak effects exerted by networks. The high legitimacy of the standards and expertise by the ILO in the field of maternity protection easily crowds out possible other channels of diffusion. The colonial network stands out as an exception but can easily be attributed to the outsize influence of the French Overseas Labor Code (1952) and the impact of the USSR on its republics. Finally, the effect of democracy defies expectations of standard welfare state theory but squares easily with the fact that the socialist countries in Eastern 
Table 7.1 Global network diffusion of paid maternity leave

\begin{tabular}{|c|c|c|c|c|c|}
\hline & \multicolumn{5}{|c|}{$\begin{array}{l}\text { Dependent variable: introduction of paid } \\
\text { maternity leave }\end{array}$} \\
\hline & (1) & (2) & (3) & (4) & (5) \\
\hline 1880-1904 & $0.002^{* * *}$ & $0.002^{* * *}$ & $0.002^{* * *}$ & $0.002^{* * *}$ & $0.002^{* * *}$ \\
\hline 1905-1929 & $0.009^{* * *}$ & $0.011^{* * *}$ & $0.012^{* * *}$ & $0.009^{* * *}$ & $0.010^{* * *}$ \\
\hline $1930-1954$ & $0.009^{* * *}$ & $0.009^{* * *}$ & $0.014^{* * *}$ & $0.009^{* * *}$ & $0.008^{* * *}$ \\
\hline 1955-1979 & $0.007^{* * *}$ & $0.008^{* * *}$ & $0.014^{* * *}$ & $0.007^{* * *}$ & $0.006^{* * *}$ \\
\hline 1980-2010 & $0.003^{* * *}$ & $0.004^{\star * *}$ & $0.007^{* * *}$ & $0.003^{* * *}$ & $0.003^{* * *}$ \\
\hline $\begin{array}{l}\text { Trade existed }(=1, \\
\text { else }=0)\end{array}$ & $3.817^{* * *}$ & $4.795^{* * *}$ & $3.683^{* * *}$ & $3.798^{\star * *}$ & $4.484^{* * *}$ \\
\hline $\begin{array}{l}\text { GDP per capita } \\
\text { (log) }\end{array}$ & $1.521^{* * *}$ & $1.543^{* * *}$ & $1.514^{* * *}$ & $1.508^{* * *}$ & $1.531^{* * *}$ \\
\hline Democratization & $0.909^{+}$ & $0.868^{* *}$ & $0.910^{+}$ & 0.916 & $0.872^{* *}$ \\
\hline ILO Membership & $1.807^{\star}$ & $1.756^{*}$ & $1.819^{* *}$ & $1.778^{*}$ & $1.652^{*}$ \\
\hline Total fertility rate & 1.058 & 0.973 & 1.038 & 1.059 & 0.978 \\
\hline $\begin{array}{l}\text { Cultural spheres } \\
\text { netw.: w. } \\
\text { exposure (lag } \\
1 \text { year) }\end{array}$ & 2.796 & & & & 0.384 \\
\hline $\begin{array}{l}\text { Colonies netw.: } \\
\text { exposure }\end{array}$ & & $3.098^{* * *}$ & & & $3.189^{* * *}$ \\
\hline $\begin{array}{l}\text { Trade net: w. } \\
\text { exposure (lag } \\
1 \text { year) }\end{array}$ & & & 1.266 & & 1.221 \\
\hline $\begin{array}{l}\text { Spatial proximity } \\
\text { netw.: w. } \\
\text { exposure (lag } \\
1 \text { year) }\end{array}$ & & & & 2.756 & 3.321 \\
\hline Observations & 10,663 & 10,817 & 10,663 & 10,663 & 10,663 \\
\hline Log Likelihood & -665.988 & -653.125 & -666.374 & -665.744 & -651.903 \\
\hline Akaike Inf. Crit & 1353.977 & 1328.25 & 1354.748 & 1353.489 & 1331.806 \\
\hline
\end{tabular}

Note ${ }^{+} p<0.1 ;{ }^{*} p<0.05 ;{ }^{* *} p<0.01 ;{ }^{* *} p<0.001$

Europe combined political disenfranchisement with the establishment of generous social rights, especially for women workers.

\section{(b) Child Benefits}

Child benefits diffused rapidly between the end of the First World War (WW1) and the 1960s. Most countries that introduced a child benefit scheme did so within this time frame. After the 1960s, new introductions 
followed slowly, with only a marginal acceleration in the 1990 s, occurring due to the diffusion of conditional cash transfers in middle-income countries.

The models in Table 7.2 are again noteworthy in that the stepwisetime-function indicates strong time dependence across all specifications. Given that the larger coefficients can be found during the interwar and postwar periods, these can carefully be interpreted as giving some indirect support to the compensation hypothesis.

Most of the other covariates included in the models are not statistically significant, but given that the sample includes a large share of the population of reference, it seems relevant to discuss at least the estimated

Table 7.2 Global network diffusion of child benefits

Dependent variable: introduction of child benefits

\begin{tabular}{lllll} 
& $(1)$ & $(2)$ & $(3)$ & $(4)$ \\
\hline $1880-1904$ & 0.000 & 0.000 & 0.000 & 0.000 \\
$1905-1929$ & $0.001^{* * *}$ & $0.002^{* * *}$ & $0.001^{* * *}$ & $0.001^{* *}$ \\
$1930-1954$ & $0.043^{* *}$ & $0.040^{* *}$ & $0.030^{* *}$ & $0.027^{* *}$ \\
$1955-1979$ & $0.062^{+*}$ & $0.027^{* *}$ & $0.022^{* *}$ & $0.019^{* *}$ \\
$1980-2010$ & $0.017^{* *}$ & $0.006^{* *}$ & $0.006^{* *}$ & $0.005^{* *}$ \\
Trade existed (=1, else $=$ & 1.522 & 1.844 & 1.314 & 1.511 \\
$\quad$ 0) & & & & \\
GDP per capita (log) & 1.154 & 1.124 & 1.161 & 1.145 \\
Democratization & 1.008 & 0.985 & 1.001 & 0.996 \\
Total fertility rate & $0.666^{* * *}$ & $0.617^{* * *}$ & $0.683^{* * *}$ & $0.690^{* * *}$ \\
ILO Membership & 0.718 & 0.638 & 0.728 & 0.749 \\
Cultural spheres netw.: w. & 0.165 & & & \\
$\quad$ exposure (lag 1 year) & & & & \\
Colonies netw.: exposure & & $2.378^{* *}$ & & \\
Trade net: w. exposure & & & 1.576 & \\
$\quad$ lag 1 year) & & & & \\
Spatial proximity netw.: w. & & & & \\
$\quad$ exposure & & & & \\
Observations & 15,124 & 15,278 & 15,124 & 15,124 \\
Log Likelihood & -464.908 & -461.165 & -465.858 & -465.743 \\
Akaike Inf. Crit & 951.816 & 944.33 & 953.717 & 953.486 \\
\hline Note & & &
\end{tabular}

Note ${ }^{+} p<0.1 ;{ }^{*} p<0.05 ;{ }^{* *} p<0.01 ;{ }^{* *} p<0.001$ 
effects. Existing states are $52-84 \%$ more likely to adopt child benefits, however, the estimates are not significant across specifications. GDP per capita is positively associated with child benefit introduction. In line with our expectations, the level of democracy does not seem to affect the hazard of introducing child benefits. The only statistically significant association is the number of births per woman. A one-unit increase in the total fertility rate reduces the hazard of introducing a child benefit by $31-38 \%$. This strongly supports the population hypothesis. Finally, even though the ILO called for the introduction of family benefits in its 1952 Social Security Convention (C102), being a member of the ILO is associated with a lower probability of introducing child benefits, but the association is again not significant.

Network exposures are similar to other policy fields displaying stable effects for the colonial and trade networks and highly unstable effects for the cultural spheres, which are highly sensitive to the inclusion of spatial proximity. Interestingly, the higher the number of countries in a country cultural network introducing child benefits (model 1), the lower the hazard of introducing child benefits. The association is, however, not significant. The colonial network exerts a high degree of influence on the adoption of child benefits, increasing the hazard by $138 \%$ on its own. Again, this is likely driven by the impact of the French Overseas Labour Code and the adoption of child benefits in the USSR. Similarly, the hazard of introducing child benefits is more than doubled when neighboring countries do so. We refrain from reporting the results of the model including all networks, because VIFs of the cultural and spatial network in this model are 13.8 and 9.7, respectively, suggesting that the coefficients are inflated due to multicollinearity.

\section{(c) Workplace Childcare Regulation}

We finally turn to the set of models dealing with the adoption of workplace childcare legislation (Table 7.3). These follow the already familiar pattern of exhibiting significant time dependency, limited national effects, and the identification of a single powerful diffusion channel. We again discuss each in turn. 
Table 7.3 Global network diffusion of workplace childcare

Dependent variable: introduction of workplace childcare legislation

\begin{tabular}{|c|c|c|c|c|c|}
\hline & (1) & (2) & (3) & (4) & (5) \\
\hline 1880-1904 & $0.0002^{* * *}$ & $0.0002^{* * *}$ & $0.0003^{* * *}$ & $0.0003^{* * *}$ & $0.0002^{* * *}$ \\
\hline 1905-1929 & $0.003^{\star \star \star}$ & $0.002^{\star \star \star}$ & $0.005^{\star \star \star}$ & $0.005^{\star * \star}$ & $0.002^{* * *}$ \\
\hline 1930-1954 & $0.004^{* * *}$ & $0.002^{* * *}$ & $0.007^{* * *}$ & $0.009^{* * *}$ & $0.003^{* * *}$ \\
\hline 1955-1979 & $0.002^{* * *}$ & $0.001^{* * *}$ & $0.004^{* * *}$ & $0.006^{* * *}$ & $0.002^{* * *}$ \\
\hline $1980-2010$ & $0.001^{* * *}$ & $0.0005^{* * *}$ & $0.001^{* * *}$ & $0.002^{* * *}$ & $0.001^{* * *}$ \\
\hline $\begin{array}{l}\text { Trade existed }(=1, \\
\text { else }=0)\end{array}$ & 1.703 & $2.021^{+}$ & 1.709 & $1.865^{+}$ & $1.932^{+}$ \\
\hline $\begin{array}{l}\text { GDP per capita } \\
\text { (log) }\end{array}$ & 1.059 & 1.103 & 1.045 & 1.048 & 1.134 \\
\hline Democratization & $0.835^{* *}$ & $0.850^{\star *}$ & $0.823^{* * *}$ & $0.819^{\star * *}$ & $0.853^{* *}$ \\
\hline Total fertilty rate & 0.938 & 0.941 & 0.920 & 0.903 & 0.915 \\
\hline ILO membership & $3.377^{\star *}$ & $3.524^{\star *}$ & $3.390^{* *}$ & $3.643^{* *}$ & $3.807^{\star *}$ \\
\hline $\begin{array}{l}\text { Cultural spheres } \\
\text { netw.: w. } \\
\text { exposure (lag } \\
1 \text { year) }\end{array}$ & 8.418 & & & & 6.672 \\
\hline $\begin{array}{l}\text { Colonies netw.: w. } \\
\text { exposure }\end{array}$ & & $3.204^{* * *}$ & & & $3.303^{* * *}$ \\
\hline $\begin{array}{l}\text { Trade net: w. } \\
\text { exposure (lag } \\
1 \text { year) }\end{array}$ & & & 1.549 & & 1.475 \\
\hline $\begin{array}{l}\text { Spatial proximity } \\
\text { netw.: w. } \\
\text { exposure (lag } \\
1 \text { year) }\end{array}$ & & & & 0.576 & $0.057^{*}$ \\
\hline Observations & 14,219 & 14,373 & 14,219 & 14,219 & 14,219 \\
\hline Log Likelihood & -519.634 & -508.983 & -520.417 & -520.548 & -507.071 \\
\hline Akaike Inf. Crit & 1061.268 & 1039.965 & 1062.834 & 1063.095 & 1042.142 \\
\hline
\end{tabular}

Just as in the models of other types of family policy, we observe a peak of global legislative activity in the interwar and immediate post-World War II period, which is reflected by the coefficients of the stepwise-timefunction. Again, this may be due to common trends, but common shocks originating in global culture and politics must also be considered. 
As is the case with the other family policies, the presence of trade (data), which de facto acts as a proxy of political independence, exerts some influence. Independent countries with their own national trade accounts are between 70 and 93\% more likely to adopt legislation mandating the private provision of factory nurseries than dependent territories. Regarding GDP per capita, our expectation of an unclear effect is substantiated by the coefficient as well as its lack of significance. We also find, contrary to expectations, a small but significant effect of regime type with more democratic regimes exhibiting a decreased hazard - by around 15-20\%—of adopting workplace childcare. While the fertility rate remains insignificant across models, it points in the expected direction decreasing the hazard of adoption by around 10\% for each child per woman. Given that the ILO has only made limited strides into the field of factory childcare until recently, the strong effect of the ILO on workplace childcare legislation-more than tripling the hazard of adoption-is surprising.

Turning to network exposition, we again find a strong effect of colonial ties on adoption, increasing hazards threefold. Similarly to the other policies, we suspect that this is largely driven by the influence of the USSR and the activity of the French colonial administration, which enacted three pieces of legislation that included nursery clauses across the French possessions: French Indochina in 1927, French Equatorial, and West Africa, both in 1954. The cultural spheres network proves to be the most unstable as well as the hardest to attach substantive meaning to, yet again. While its effects point in the expected direction in models 1 and 5, its inclusion substantially alters the effect of spatial proximity. We suspect that cultural similarity does not function as a channel of diffusion wholesale, but only for a much more restricted set of countries or cultures.

\section{Discussion and Conclusion}

Overall, the results of the discrete-time-hazard models are in some ways sobering: they did little to identify channels of diffusion, whose presence was not established by earlier research. However, as a test of existing 
hypotheses, they broaden our understanding by expanding the historical, spatial, and policy-specific reach of previous analysis.

Paid maternity leave, as the earliest form of decommodification as well as defamilization for women, is confirmed as a showcase for the agenda-setting power of the ILO. Regardless of the ratification of specific conventions, continuous advocacy and technical assistance have urged more and more countries to fulfill the standards laid out in its conventions.

Family allowances or child benefits, while also being advocated for by the ILO, seem, except for the 'imperial diffusion' (Kuhlmann et al. 2020) through the Code du Travail, to be driven more by domestic concerns in comparison. Our models provide the first test of the hypothesis that low fertility levels spur the adoption of benefits toward families with children, i.e., the emergence of family policy as population policy. However, this should not be interpreted as a purely domestic mechanism, since fears of population decline were often understood in terms of comparative military strength (Barrett and Frank 1999). The relational and transnational dimension of the "population hypothesis" is captured through the inclusion of the stepwise-time-function in our models: Coefficients reflect effects relative to a period's baseline hazard, which in turn implies that cross-country trends in fertility are captured by the stepwise-timefunction. Hence, what is modeled is the effect of fertility relative to the general level during each time period, which provides a very rough proxy for processes of mutual observation.

Finally, we analyzed the adoption of workplace childcare regulations, which have not been analyzed within comparative social policy literature so far. Due to data limitations, we could not test the most prominent hypothesis found in the historical literature which connects the adoption of factory nurseries to infant mortality. We do, however, find that colonial networks, with the French again standing out, exert an outsized influence on adoption.

Across models, we find instructive patterns of time-dependency. We have refrained from giving much substantive weight to these since in itself "time is not a theoretical variable" (Beck 2010). Yet, mentions of 
trends, phases, and periods that cut across cases and signify deep structural shifts in the global environment of policymaking permeate the family policy (Daly and Ferragina 2018) and the broader welfare state literature (Nullmeier and Kaufmann 2010). Scholars in the tradition of world-society theory go so far as to assign explanatory primacy to the global level, treating national legislative activity as mere emanations of a "transnational event" (Abbott and DeViney 1992). The baseline hazards of all three policies indicate that the early twentieth century (paid maternity leave) and the interwar years (child benefits and workplace childcare) are decisive periods with heightened legislative activity across varied national contexts. This suggests linking the emergence of family policy to industrialization, but also to the ideational and political shifts of the early twentieth century.

While the inclusion of networks is clearly a step forward in modeling linkages between countries, their construction raises challenges and needs to be informed by theory and historical case knowledge. The colonial network, in particular, suffers from treating linkages alike, whose effects differ systematically not only between colonizing/imperial powers but also within colonial empires according to previous research (Lange 2004; Schmitt 2015). Results of auxiliary regressions with nonnormalized exposure (see appendix) display more pronounced effects of colonial/imperial ties, indicating that family policies spread via direct imperial linkages rather than colonial legacies.

Despite these caveats, our analysis has highlighted that some of the main hypotheses identified by earlier research, which looked at a much smaller set of cases and a much shorter time frame, do in fact "travel" across time and space. It has also shown that colonial and other imperial relations play an important role in the origin of family policies outside of Western Europe. While these analyzes do not say anything explicitly about the trajectories that followed introduction, earlier research demonstrated that family policy in Europe developed through a process of "layering" (Daly and Ferragina 2018), suggesting that the identified drivers have lasting effects which will shape family policy across the world for decades to come. 


\section{Appendix}

See Tables 7.4, 7.5, and 7.6.

Table 7.4 Global network diffusion of paid maternity leave (alternative)

\begin{tabular}{lll}
\hline & \multicolumn{2}{l}{$\begin{array}{l}\text { Dependent variable: } \\
\text { introduction of paid } \\
\text { maternity leave }\end{array}$} \\
\cline { 2 - 3 } & $(1)$ & $(2)$ \\
\hline $1880-1904$ & $0.002^{* * *}$ & $0.002^{* * *}$ \\
$1905-1929$ & $0.010^{* * *}$ & $0.009^{* * *}$ \\
$1930-1954$ & $0.009^{* * *}$ & $0.006^{* * *}$ \\
$1955-1979$ & $0.007^{* * *}$ & $0.004^{* * *}$ \\
$1980-2010$ & $0.005^{* * *}$ & $0.002^{* * *}$ \\
Trade existed (=1, else $=0)$ & $6.280^{* * *}$ & $5.444^{* * *}$ \\
GDP per capita (log) & $1.523^{* * *}$ & $1.530^{* * *}$ \\
Democratization & $0.902^{*}$ & $0.899^{*}$ \\
ILO membership & $1.929^{* *}$ & $1.699^{*}$ \\
Total fertility rate & 0.948 & 0.968 \\
Cultural spheres netw.: w. exposure (lag 1 year) & & 2.394 \\
Non normalized colonies netw.: exposure & $3.247^{* * *}$ & $3.333^{* * *}$ \\
Trade net: w. exposure (lag 1 year) & & 1.502 \\
Spatial proximity netw.: w. exposure (lag 1 year) & & 0.938 \\
Observations & 10,817 & 10,663 \\
Log Likelihood & -649.41 & -648.054 \\
Akaike Inf. Crit & 1320.82 & 1324.109 \\
\hline Note & &
\end{tabular}

Note ${ }^{+} p<0.1 ;{ }^{*} p<0.05 ;{ }^{* *} p<0.01 ;{ }^{* *} p<0.001$

Table 7.5 Global network diffusion of child benefits (alternative)

\begin{tabular}{ll}
\hline & $\begin{array}{l}\text { Dependent variable: introduction of } \\
\text { child benefits } \\
(1)\end{array}$ \\
\hline $1880-1904$ & 0.000 \\
$1905-1929$ & $0.001^{* * *}$ \\
$1930-1954$ & $0.020^{* * *}$ \\
$1955-1979$ & $0.012^{* * *}$ \\
$1980-2010$ & $0.003^{* * *}$ \\
Trade existed $(=1$, else $=0)$ & $3.373^{*}$ \\
\hline
\end{tabular}


Table 7.5 (continued)

Dependent variable: introduction of child benefits

(1)

GDP per capita (log)

$1.156^{+}$

Democratization

0.974

Total fertility rate

$0.598^{* * *}$

ILO Membership

0.754

Cultural spheres netw.: w. exposure (lag

1 year)

Non normalized colonies netw.: exposure

Trade net: $w$. exposure (lag 1 year)

Spatial proximity netw.: w. exposure

Observations

15,278

Log Likelihood

Akaike Inf. Crit

928.594

Note ${ }^{+} p<0.1 ;{ }^{*} p<0.05 ;{ }^{* *} p<0.01 ;{ }^{* *} p<0.001$

Table 7.6 Global network diffusion of workplace childcare (alternative)

\begin{tabular}{|c|c|c|}
\hline & \multicolumn{2}{|c|}{$\begin{array}{l}\text { Dependent variable: } \\
\text { Introduction of } \\
\text { Workplace Childcare } \\
\text { Legislation }\end{array}$} \\
\hline & $\overline{(1)}$ & (2) \\
\hline 1880-1904 & $0.0004^{* * *}$ & $0.0003^{* * *}$ \\
\hline 1905-1929 & $0.004^{* * *}$ & $0.004^{\star * *}$ \\
\hline 1930-1954 & $0.005^{* * *}$ & $0.004^{* * *}$ \\
\hline 1955-1979 & $0.003^{* * *}$ & $0.002^{* * *}$ \\
\hline $1980-2010$ & $0.001^{* * *}$ & $0.001^{* * *}$ \\
\hline Trade existed $(=1$, else $=0)$ & $2.412^{*}$ & $2.163^{+}$ \\
\hline GDP per capita (log) & 1.027 & 1.060 \\
\hline Democratization & $0.845^{* *}$ & $0.855^{*}$ \\
\hline Total fertility rate & $0.870^{*}$ & $0.867^{+}$ \\
\hline ILO membership & $3.700^{* *}$ & $3.835^{* *}$ \\
\hline Cultural spheres netw.: w. exposure (lag 1 year) & & 14.448 \\
\hline Non normalized colonies netw.: exposure & $4.517^{* * *}$ & $4.491^{* * *}$ \\
\hline Trade net: w. exposure (lag 1 year) & & 1.749 \\
\hline Spatial proximity netw.: w. exposure (lag 1 year) & & $0.077^{+}$ \\
\hline Observations & 14,373 & 14,219 \\
\hline Log Likelihood & -503.793 & -501.746 \\
\hline Akaike Inf. Crit & 1029.587 & 1031.491 \\
\hline
\end{tabular}

Note ${ }^{+} p<0.1 ;{ }^{*} p<0.05 ;{ }^{* *} p<0.01 ;{ }^{* *} p<0.001$ 


\section{Literature}

Abbott, Andrew, and Stanley DeViney. 1992. "The Welfare State as Transnational Event: Evidence from Sequences of Policy Adoption." Social Science History 16 (2): 245-274.

Aguilar, Paula Lucía. 2018. "Motherhood at the Heart of Labour Regulation: Argentina, 1907-1941." In Women's ILO: Transnational Networks, Global Labour Standards and Gender Equity, 1919 to Present, edited by E. Boris, D. Hoehtker, and S. Zimmermann, 255-275. Leiden, Boston: Brill.

Barrett, Deborah, and David John Frank. 1999. "Population Control for National Development: From World Discourse to National Policies." In International Nongovernmental Organizations Since 1875, J. Boli and G. M. Thomas, 198-221. Stanford, CA: Stanford University Press.

Beck, Nathaniel. 2010. “Time Is Not a Theoretical Variable.” Political Analysis 18 (3): 293-294.

Berkovitch, Nitza. 1999. From Motherhood to Citizenship. Baltimore: Johns Hopkins University Press.

Biagi, Bruno. 1937. "Family Allowances in Italy." International Labor Review 35: 457.

Blofield, M., and J. Martinez Franzoni. 2015. "Maternalism, Co-responsibility, and Social Equity: A Typology of Work-Family Policies." Social Politics 22 (1): 38-59.

Blofield, Merike, and Michael Touchton. 2020. "Moving Away from Maternalism? The Politics of Parental Leave Reforms in Latin America." Comparative Politics 53 (1): 1-27.

Boris, Eileen. 2019. Making the Woman Worker: Precarious Labor and the Fight for Global Standards, 1919-2019. Oxford: Oxford University Press.

Breul, Frank R. 1953. "The Genesis of Family Allowances in Canada." Social Service Review 27 (3): 269-280.

Burger, Kaspar. 2012. "A Social History of Ideas Pertaining to Childcare in France and in the United States." Journal of Social History 45 (4): 10051025.

Campbell, R. M. 1927. "Family Allowances in New Zealand." The Economic Journal 37 (147): 369-383.

Caroli, Dorena. 2019. "Day Nurseries in Europe in the Nineteenth and Twentieth Centuries: The Challenge of the Transnational Approach." In the Transnational in the History of Education: Concepts and Perspectives, E. 
Fuchs and E. Roldán Vera. 1st ed., 69-100. Cham: Springer International Publishing.

Casas, Lidia, and Tania Herrera. 2012. "Maternity Protection vs. Maternity

Rights for Working Women in Chile: A Historical Review." Reproductive Health Matters 20 (40): 139-147.

Collier, David, and Richard E. Messick. 1975. "Prerequisites Versus Diffusion: Testing Alternative Explanations of Social Security Adoption.” American Political Science Review 69 (4): 1299-1315.

Cooper, Frederick. 1996. Decolonization and African Society. Cambridge: Cambridge University Press.

Cousins, Mel. 1999. "The Introduction of Children's Allowances in Ireland 1939-1944." Irish Economic and Social History 26 (1): 35-53.

Daly, Mary, and Emanuele Ferragina. 2018. "Family Policy in High-Income Countries: Five Decades of Development." Journal of European Social Policy 28 (3): 255-270.

Darwin, Leonard. 1925. "Family Allowances." The Eugenics Review 16 (4): 276. Doublet, Jacques. 1948. "Family Allowances in France." Population Studies 2 (2): 219-239.

Esping-Andersen, Gøsta. 1990. The Three Worlds of Welfare Capitalism. Princeton: Princeton University Press.

Ferrarini, Tommy. 2006. Families, States and Labour Markets: Institutions, Causes and Consequences of Family Policy in Post-War Welfare States. Celtenham, UK: Edward Elgar Publishing.

Filgueira, Fernando, and Cecilia Rossel. 2020. "Family Policies Across the Globe." In The Palgrave Handbook of Family Policy, R. Nieuwenhuis and W. van Lancker, 219-247. Cham: Springer International Publishing.

Fleckenstein, Timo, and Soohyun Christine Lee. 2017. "The Politics of Investing in Families: Comparing Family Policy Expansion in Japan and South Korea." Social Politics 24 (1): 1-28.

Flora, Peter, and Arnold J. Heidenheimer. 1981. The Development of Welfare States in Europe and America. London: Transaction Books.

Gapminder. 2020. "Babies Per Woman (Total Fertility Rate) \& GDP Per Capita in Constant PPP Dollars: Data." https://www.gapminder.org/data/. Gauthier, Anne Helène. 1996. The State and the Family: A Comparative Analysis of Family Policies in Industrialized Countries. Oxford: Oxford University Press.

Gille, Halvor. 1954. "Scandinavian Family Allowances Demographic Aspects." Eugenics Quarterly 1 (3): 182-190. 
Hein, Catherine, and Naomi Cassirer. 2010. Workplace Solutions for Childcare. Geneva: International Labour Office.

Hobson, Barbara, and Marika Lindholm. 1997. "Collective Identities, Women's Power Resources, and the Making of Welfare States." Theory and Society 26 (4): 475-508.

Hoffner, Claire. 1935. "Compulsory Payment of Family Allowances in Belgium, France, and Italy." International Labour Review 32: 463.

Hoffner, Claire. 1940. "Recent Developments in Compulsory Systems of Family Allowances." International Labour Review 41: 337.

Htun, Mala, Francesca R. Jensenius, and Jami Nelson-Nuñez. 2019. "GenderDiscriminatory Laws and Women's Economic Agency.” Social Politics 26 (2): 193-222.

Kangas, Olli E. 2012. "Testing Old Theories in New Surroundings: The Timing of First Social Security Laws in Africa." International Social Security Review 65 (1): 73-97.

Kitchen, Brigitte. 1981. "Wartime Social Reform: The Introduction of Family Allowances." Canadian Journal of Social Work Education/Revue Canadienne d'Éducation en Service Social: 29-54.

Koven, Seth, and Sonya Michel. 1990. "Womanly Duties: Maternalist Politics and the Origins of Welfare States in France, Germany, Great Britain, and the United States, 1880-1920." The American Historical Review 95 (4): 1076.

Kuhlmann, Johanna, Delia González de Reufels, Klaus Schlichte, and Frank Nullmeier. 2020. "How Social Policy Travels: A Refined Model of Diffusion." Global Social Policy 20 (1): 80-96.

Land, Hilary. 1985. "The Introduction of Family Allowances: An Act of Historic Justice?" In Women and Social Policy, Clare Ungerson, 9-29. London: Palgrave.

Lange, Matthew K. 2004. "British Colonial Legacies and Political Development.” World Development 32 (6): 905-922.

Leitner, Sigrid. 2003. "Varieties of Familialism: The Caring Function of the Family in Comparative Perspective." European Societies 5 (4): 353-375.

Linos, Katerina. 2013. The Democratic Foundations of Policy Diffusion. Oxford: Oxford University Press.

Meyer, John W., John Boli, George M. Thomas, and Francisco O. Ramirez. 1997. "World Society and the Nation-State." American Journal of Sociology 103 (1): 144-181.

Misra, Joya. 1998. "Mothers or Workers? The Value of Women's Labor: Women and the Emergence of Family Allowance Policy." Gender and Society 12 (4): 376-399. 
Misra, Joya. 2003. "Women as Agents in Welfare State Development: A CrossNational Analysis of Family Allowance Adoption." Socio-Economic Review 1 (2): 185-214.

Nullmeier, Frank, and Franz-Xaver Kaufmann. 2010. "Post-War Welfare State Development." In the Oxford Handbook of the Welfare State, F. G. Castles, S. Leibfried, J. Lewis, H. Obinger, and C. Pierson. Oxford: Oxford University Press.

Obinger, Herbert, and Carina Schmitt. 2020. "World War and Welfare Legislation in Western Countries." Journal of European Social Policy 30 (3): 261-274.

O'Connor, Sorca M. 1990. "Rationales for the Institutionalization of Programs for Young Children." American Journal of Education 98 (2): 114-146.

Orloff, Ann Shola. 1993. "Gender and the Social Rights of Citizenship: The Comparative Analysis of Gender Relations and Welfare States." American Sociological Review 58 (3): 303-328.

Rathbone, Eleanor Florence. 1940. The Case for Family Allowances. London: Penguin Books, Inc.

Reynolds, Siân. 1990. "Who Wanted the Crèches? Working Mothers and the Birth-Rate in France 1900-1950." Continuity and Change 5 (2): 173-197. Sainsbury, Diane. 2001. "Gender and the Making of Welfare States: Norway and Sweden." Social Politics 8 (1): 111-142.

Saraceno, Chiara. 2011. "Childcare Needs and Childcare Policies: A Multidimensional Issue.” Current Sociology 59 (1): 78-96.

Saraceno, Chiara. 2016. "Varieties of Familialism: Comparing Four Southern European and East Asian Welfare Regimes." Journal of European Social Policy 26 (4): 314-326.

Schmitt, Carina. 2015. "Social Security Development and the Colonial Legacy." World Development 70: 332-342.

Schmitt, Carina. 2020. "The Warfare-Welfare Nexus in French African Colonies in the Course of the First and Second World War." Historical Social Research/Historische Sozialforschung 45 (2) (172): 217-238.

Schmitt, Carina, Hanna Lierse, Herbert Obinger, and Laura Seelkopf. 2015. “The Global Emergence of Social Protection.” Politics \& Society 43 (4): 503524.

Son, Keonhi, and Tobias Böger. 2021. "The Inclusiveness of Maternity Leave Rights Over 120 Years and Across 5 Continents.” Social Inclusion 9 (2): 275-287.

Son, Keonhi, Tobias Böger, Simone Tonelli, Petra Buhr, Sonja Drobnič, and Johannes Huinink. 2020. "Codebook of Historical Database on Maternity 
Leave (HDML).” SFB 1342 Technical Paper Series. https://www.socialpol icydynamics.de/crc-publications/crc-1342-technical-paper-series.

Therborn, Göran. 2004. Between Sex and Power: Family in the World 19002000. London: Routledge.

Tonelli, Simone, Tobias Böger, Keonhi Son, Petra Buhr, Sonja Drobnič, and Johannes Huinink. 2021. "Codebook of Historical Dataset of Child Benefit (HDCB).” SFB 1342 Technical Paper Series. https://www.socialpolicydyn amics.de/crc-publications/crc-1342-technical-paper-series.

Valente, Thomas Q. 1995. "Network Models of the Diffusion of Innovations".

New Jersey: Hampton.

Watson, Cicely. 1954a. "Population Policy in France: Family Allowances and Other Benefits II." Population Studies 8 (1): 46-73.

Watson, Cicely. 1954b. "Population Policy in France: Family Allowances and

Other Benefits. I." Population Studies 7 (3): 263-286.

White, Linda A. 2020. "Do International Organizations Influence Domestic

Policy Outcomes in OECD Countries?" In the Palgrave Handbook of

Family Policy, R. Nieuwenhuis and W. van Lancker. 1st ed. 2020, 69-86.

Basingstoke: Palgrave Macmillan.

Open Access This chapter is licensed under the terms of the Creative Commons Attribution 4.0 International License (http://creativecommons.org/ licenses/by/4.0/), which permits use, sharing, adaptation, distribution and reproduction in any medium or format, as long as you give appropriate credit to the original author(s) and the source, provide a link to the Creative Commons license and indicate if changes were made.

The images or other third party material in this chapter are included in the chapter's Creative Commons license, unless indicated otherwise in a credit line to the material. If material is not included in the chapter's Creative Commons license and your intended use is not permitted by statutory regulation or exceeds the permitted use, you will need to obtain permission directly from the copyright holder.

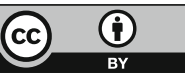

